\title{
CHARACTERIZATION OF VIRULENCE GENES cagA AND vacA IN HELICOBACTER PYLORI AND THEIR PREVALENCE IN GASTROINTESTINAL DISORDERS
}

\section{Laura Lúcia Cogo ${ }^{1,2^{*}}$, Cristina Leise Bastos Monteiro ${ }^{2}$, Keite da Silva Nogueira ${ }^{1,3}$, Jussara Kasuko Palmeiro ${ }^{1}$, Marcelo Lima Ribeiro ${ }^{5}$, Eloá Ramalho de Camargo ${ }^{5}$, Daniel Locatelli Neves ${ }^{4}$, Aguinaldo José do Nascimento ${ }^{3}$, Libera Maria Dalla Costa $^{1,2,3}$}

${ }^{1}$ Hospital de Clínicas da Universidade Federal do Paraná, Curitiba, PR, Brasil; ${ }^{2}$ Programa de Pós-Graduação em Processos Biotecnológicos da Universidade Federal do Paraná, Curitiba, PR, Brasil; ${ }^{3}$ Programa de Pós-Graduação em Ciências Farmacêuticas da Universidade Federal do Paraná, Curitiba, PR, Brasil; ${ }^{4}$ Hospital do Trabalhador, Curitiba, PR, Brasil; ${ }^{5}$ Laboratório de Microbiologia e Biologia Molecular da Unidade Integrada de Farmacologia e Gastroenterologia da Universidade São Francisco, Bragança Paulista, SP, Brasil.

Submitted: July 20, 2010; Returned to authors for corrections: April 06, 2011; Approved: June 06, 2011.

\begin{abstract}
Prevalence of $H$. pylori infection was determined using cultures of gastric biopsy samples of patients attended at the academic hospital of the Federal University of Paraná, Curitiba, Paraná, Brazil. Molecular methods were used to characterize the $\operatorname{cag} A$ and $v a c A$ genes from bacterial isolates associated with different diseases presented by patients. Out of a total of 81 , forty-two gastric biopsy samples tested were positive for H. pylori, with a prevalence of $51.9 \%$. No significant difference was found with regard to the gender ( $p=0.793)$ and age $(p=0.183)$ of the patients. Genotype $\mathrm{s} 1 \mathrm{ml} v a c A$ gene was found in $67 \%$ of the cases of peptic ulcer investigated $(p=1.0)$, despite the limited number of patients with this disease $(\mathrm{n}=3)$. A correlation between the presence of less virulent strains (s2m2) and reflux esophagitis was found in the majority of the cases (45\%), but without statistical significance. An association between the prevalence of cagA gene, found in $92 \%$ of isolates, and peptic ulcer was not observed $(p=1.0)$, suggesting that this gene cannot be considered a specific marker of severity in our environment. The results reinforce the importance of conducting regional studies and the need to characterize $H$. pylori virulence genes associated with different diseases.
\end{abstract}

Key words: Helicobacter pylori; virulence genes; cagA; vacA.

\section{INTRODUCTION}

Helicobacter pylori is a gram-negative, microaerophilic, spiral rod-shaped bacillus that, since it was discovered in 1983, has been associated with the etiopathogenesis of several diseases of the digestive system (11). This bacterium colonizes the gastric mucosa of more than half of the world's population $(8,9)$ and is recognized as the main cause of histological

*Corresponding Author. Mailing address: Hospital de Clínicas da Universidade Federal do Paraná, Curitiba, PR, Brasil;.; E-mail: lauracogo@ufpr.br 
gastritis, the majority of peptic ulcers, in addition to being involved in the development of adenocarcinomas of the stomach and primary gastric mucosa-associated lymphoid tissue lymphoma (26).

Although most individuals do not develop adverse clinical consequences from $H$. pylori colonization, between 10 and $15 \%$ will experience some form of symptomatology (13) and the clinical result of the infection will be determined by complex interactions between host and bacterial factors. While the host factors remain unknown, the identification of specific bacterial factors is continuously advancing (16).

Over the past few years, research on pathogenicity markers has become gradually more important and intense in an attempt to detect bacterial strains associated with each of these diseases. The cytotoxin-associated gene A ( $\operatorname{cag} A$ gene) was the first virulence factor detected in H. pylori strains. This gene encodes a protein that is associated with an increase in intensity of gastric inflammation and, consequently, with severe clinical outcomes, inducing an intense inflammatory process, with dense neutrophil infiltration, which can cause severe damage to the gastric mucosa (17).

The vacA gene (vacuolating cytotoxin gene $A$ ) - another important virulence factor - encodes the production of a vacuolating cytotoxin. The activity of this cytotoxin causes cytoskeleton changes, apoptosis and vacuolation of host cells (19). Although the vacA gene is present in almost all $H$. pylori strains, only half produce cell vacuolation in vitro, suggesting genetic diversity (2).

The vacA gene has two variable regions, the $s$ region which encodes the signal peptide and exists as two alleles, s1 or $\mathrm{s} 2$ - and the $\mathrm{m}$ region - which is located in the middle region of the gene and has the $\mathrm{m} 1$ or $\mathrm{m} 2$ alleles. The mosaic combination of the alleles of the s region with the alleles of the $\mathrm{m}$ region allelic types determines cytotoxin production and activity and is responsible for the degree of virulence of the bacterium $(3,27)$. Bacterial strains classified as type $\mathrm{s} 1 \mathrm{~m} 1$ are associated with the production of high levels of vacuolating cytotoxin, type $\mathrm{s} 1 \mathrm{~m} 2$ strains produce moderate levels, while type $\mathrm{s} 2 \mathrm{~m} 2$ show little or no vacuolating cytotoxin production (19).

In addition to the genetic diversity among $H$. pylori strains, epidemiologic studies have demonstrated that the microrganism is also not evenly distributed among population groups and varies greatly with age, race, social economic conditions and geographical region (7). Differences in infection rates may be observed within the same country, particularly in Brazil with its continental dimensions and socioeconomic inequalities.

Since $H$. pylori is considered a risk factor for the development of numerous pathologies, including gastric cancer, it is relevant not only to determine the prevalence of $H$. pylori in our region, but also to associate the presence of the $\operatorname{cag} A$ and vacA virulence genes with the different diseases manifested by the patients investigated in this study.

\section{PATIENTS, MATERIAL AND METHODS}

\section{Casuistics and samples}

This study included patients attended at the hospital of the Federal University of Paraná (Hospital de Clínicas, HC-UFPR) located in the city of Curitiba - Paraná, Brazil, which had been diagnosed with gastritis (GT), peptic ulcer (PU) or reflux esophagitis (RE) based on the results of endoscopic and anatomopathological examinations. The present study was submitted to the Ethics Committee of HC-UFPR for approval (protocol CEP 982.021/2005-01). The participating patients signed a free informed consent form prior to sample collection.

The study was conducted with a total of 81 patients, 18 of which were male and 63 female, with age varying from 20 to 80 (mean \pm 47 ) years. Gastroduodenal biopsies were obtained by upper digestive endoscopy, with one biopsy being taken from the gastric corpus and another from the gastric antrum of each patient.

\section{Bacterial identification}

The samples were macerated and plated onto Petri dishes 
containing a culture medium consisting of brain heart infusion agar (Difco, MI, USA) with 10\% defribinated sheep blood (Newprov, Curitiba, Brazil), amphotericin B (10mg/L), vancomicin $(10 \mathrm{mg} / \mathrm{L})$, nalidixic acid $(20 \mathrm{mg} / \mathrm{L})$, and triphenyltetrazolium chloride (Merck, Darmstadt, Germany) $(40 \mathrm{mg} / \mathrm{L})(22)$. The dishes were incubated at $37^{\circ} \mathrm{C}$ under microaerophilic conditions, for a period of 7 days (18).

The colonies that formed in the selective medium were Gram-stained and subjected to complementary biochemical tests. The microrganism was identified as $H$. pylori if it had developed small, round smooth colonies with a golden appearance (22) with the typical cell morphology of a gramnegative spiral rod-shaped bacillus after Gram-staining. Additionally, it was tested positive for catalase, oxidase and urease (18).

After identification, part of the growth was removed with a sterile swab and transferred to a microcentrifuge tube containing $500 \mu \mathrm{L}$ chemically pure water. The suspension was centrifuged at $6000 \mathrm{x}$ g for 5 minutes and the supernatant fluids discarded. The pellet was stored in a freezer at $-80^{\circ} \mathrm{C}$ until DNA extraction (2).

\section{DNA extraction}

In this stage, $300 \mu \mathrm{L}$ of an extraction buffer solution (Tris$\mathrm{HCl} 50 \mathrm{mM}$ pH 8.0; EDTA and Tween 20 0.5\%) was added to the cryotubes containing the $H$. pylori pellets and subsequently mixed by inversion. After that, Proteinase K (Sigma Chemical CO., St. Louis, MO) was added to a final concentration of 0.5 $\mathrm{mg} / \mathrm{mL}$. The samples were then incubated at $37^{\circ} \mathrm{C}$ overnight and the bacterial DNA extracted using the phenol/chloroform method (23).

\section{Amplification of virulence genes by Polymerase Chain Reaction (PCR)}

The $\operatorname{cag} A$ and $v a c A$ virulence genes (alleles s1, s2, m1, $\mathrm{m} 2$ ) of the clinical isolates were amplified by the polymerase chain reaction in a final volume of $50 \mu \mathrm{L}$ containing $2.5 \mu \mathrm{L}$ genomic DNA, 20 pmol of each primer, $200 \mu \mathrm{M}$ of each dNTP
(Invitrogen Life Technologies, Carlsbad, EUA), $1.5 \% \mathrm{MgCl}_{2}$, 2.5 units of the Taq DNA Polimerase enzyme (Invitrogen Life Technologies, Carlsbad, EUA) and a reaction buffer for the enzyme. The $\operatorname{cag} A$ gene was analyzed using the D008/R008 primers (14). For the amplification of $v a c A \mathrm{~m}$ region, VA3R/VA3-F primers were used for type $\mathrm{ml}$, VA4-R/VA4-F primers for type $\mathrm{m} 2$ and the $\mathrm{s}$ region was amplified with VA1R/VA1-F primers (3). Positive and negative controls were used in all experiments and the PCR amplified products were analyzed by $2 \%$ agarose gel electrophoresis.

\section{Statistical Analysis}

The results were statistically analyzed using the Chisquare or Fisher's exact test. The level of significance was set at $\mathrm{p}<0.05$.

\section{RESULTS}

Of the 81 patients included in this search, 42 (51.9\%; CI95\%: 42.0\% - 62.7\%) presented positive culture for $H$. pylori, with three of the patients $(7.1 \%)$ presenting growth only in the biopsy of the gastric corpus, six patients $(14.3 \%)$ in the biopsy of the antrum, while 33 patients (78.6\%) were positive for $H$. pylori growth in both biopsy cultures.

In general, no statistically significant differences were observed for the prevalence of $H$. pylori as a function of gender ( $p=0.793$ ). The prevalence of $H$. pylori in five age subgroups $20-29 ; 30-39 ; 40-49 ; 50-59$; and 60-80 years - depicted in Table 1 - show that prevalence increased with age up to 60 years and then slightly decreased, but without reaching statistical significance $(p=0.183)$.

Examination of the different alleles of the vacA gene showed that three samples $(7.1 \%)$ were found to have more than one allelic form simultaneously, besides being present in different pathologies in these patients (one had GT, one had GT and RE, and another had GT, RE and PU; all of them presented the $\mathrm{s} 1 \mathrm{~m} 1, \mathrm{~s} 1 \mathrm{~m} 2, \mathrm{~s} 2 \mathrm{~m} 1$ e $\mathrm{s} 2 \mathrm{~m} 2$ alleles). For that 
reason, the samples were not included in the statistical analyses of this study, thus reducing the number of bacterial isolates to 39. The distribution of $v a c A$ and $\operatorname{cag} A$ genotypes found in patients suffering from gastritis, peptic ulcer and reflux esophagitis is shown in Table 2.

The associations between the vacA genotypes and clinical manifestations exhibited by the patients, such as those between reflux esophagitis and the $\mathrm{s} 2 \mathrm{~m} 2$ allele $(p=0.718)$, and peptic ulcer and the $\mathrm{s} 1 \mathrm{~m} 1$ allele $(p=1.0)$, were not statistically significant.

The $\operatorname{cag} A$ gene was found to be present in the majority of the samples analyzed (92\%) and a comparison between the presence of the gene and the different pathologies studies did not show any significant association $(p=1.0)$.

Table 1. Characteristics of the population studied by gender and age.

\begin{tabular}{lcccc}
\hline Variable & Total of Patients & Hp+ Group & Prevalence & p-value \\
\hline Gender & & & & \\
Male & 18 & 10 & $56 \%$ & 0.793 \\
Female & 63 & 32 & $51 \%$ & \\
Age (years) & & & & \\
$20-29$ & 8 & 2 & $25 \%$ & \\
$30-39$ & 7 & 3 & $43 \%$ & \\
$40-49$ & 22 & 12 & $54 \%$ & \\
$50-59$ & 25 & 15 & $60 \%$ & 0.183 \\
$60-80$ & 19 & 10 & $53 \%$ & \\
\hline
\end{tabular}

${ }^{*} \mathrm{Hp}+$ Group: patients with a positive culture for H. pylori

Table 1. Distribution of $v a c A$ and $\operatorname{cag} A$ genotypes according to the main pathologies of the patients.

\begin{tabular}{|c|c|c|c|c|}
\hline \multirow{2}{*}{ Genotype } & \multirow{2}{*}{ Total } & \multicolumn{3}{|c|}{ Pathologies } \\
\hline & & GT $^{*}(n=25)$ & $\mathrm{PU}^{* *}(\mathrm{n}=3)$ & $\mathrm{RE}^{* * *}(\mathrm{n}=11)$ \\
\hline \multicolumn{5}{|l|}{$\operatorname{cagA}$} \\
\hline $\operatorname{cag} \mathrm{A}+$ & $36(92)$ & $22(88)$ & $3(100)$ & $11(100)$ \\
\hline $\operatorname{cagA}-$ & $3(8)$ & $3(12)$ & $0(0)$ & $0(0)$ \\
\hline \multicolumn{5}{|l|}{$v a c \mathrm{~A}$} \\
\hline s1 & $23(59)$ & $15(60)$ & $2(67)$ & $6(55)$ \\
\hline $\mathrm{s} 2$ & $16(41)$ & $10(40)$ & $1(33)$ & $5(45)$ \\
\hline $\mathrm{m} 1$ & $21(54)$ & $15(60)$ & $2(67)$ & $4(36)$ \\
\hline $\mathrm{m} 2$ & $18(46)$ & $10(40)$ & $1(33)$ & $7(64)$ \\
\hline $\mathrm{s} 1 \mathrm{~m} 1$ & $20(51)$ & $14(56)$ & $2(67)$ & $4(36)$ \\
\hline $\mathrm{s} 1 \mathrm{~m} 2$ & $3(8)$ & $1(4)$ & $0(0)$ & $2(18)$ \\
\hline $\mathrm{s} 2 \mathrm{~m} 2$ & $15(38)$ & $9(36)$ & $1(33)$ & $5(45)$ \\
\hline $\mathrm{s} 2 \mathrm{~m} 1$ & $1(3)$ & $1(4)$ & $0(0)$ & $0(0)$ \\
\hline
\end{tabular}

Results expressed by frequency (percent)

${ }^{*}$ gastritis (GT) ; ${ }^{* *}$ peptic ulcer (PU) ; ${ }^{* * *}$ reflux esophagitis (RE) 


\section{DISCUSSION}

H. pylori is responsible for one of the most commonly ocurring bacterial infections in the world and its prevalence is well-documented in several countries. However, in Brazil there is only a limited number of epidemiological reports. An epidemiological study conducted by Pilonetto in 2001 (21), revealed that seroprevalence of $H$. pylori infection in the city of Curitiba was $52.9 \%$. The similar rates $(51.9 \%)$ of our study confirm the high rate of infection in our environment.

It was also observed that, in spite of the lack of statistical significance $(p=0.183), H$. pylori prevalence increased with age. This can be attributed to the cohort effect, in which the higher incidence observed in adult and elderly individuals reflects the greater risk of acquiring the infection these people were exposed to in their childhood (5). The results also demonstrate a slight drop in the H. pylori prevalence rate in the age group 60-80 years. Some authors report that a decrease in the prevalence of this microrganism in the gastric mucosa of elderly individuals may occur due to a reduction of the $H$. pylori-specific immune response, or that a reduction of the number of microrganisms in individuals that have been infected for several decades may occur as a result of gastric atrophy (25). No significant difference $(p=0.793)$ in the prevalence of $H$. pylori infection between male and female patients was found in this study, a finding which is confirmed by studies conducted by Brown (7).

The diagnosis of $H$. pylori infection by invasive means, as is the case of cultures, allowed isolating the microrganism from biopsies of both the gastric body and antrum of most of the patients $(78.6 \%)$. However, in a minority, H. pylori growth was detected only in the corpus $(7.1 \%)$ or antrum $(14.3 \%)$ biopsies. In order to study the presence of $H$. pylori in the stomach, biopsies may be taken of the mucosa of either the body or the antrum, but it is not clear in which of these two anatomical sites should be used. Some researchers suggest that the examination of biopsies of both the antrum and the corpus would be a better option for the diagnosis of the infection (12). The findings of our study suggest that the probability of positive diagnosis may be greater when cultures of both anatomic sites are examined.

PCR using allele-specific primers was performed to allow the identification of vacA types $\mathrm{s} 1$ and $\mathrm{s} 2$ of $H$. pylori isolates, the majority of these isolates (59\%) was classified as type s1 and the rest (41\%) as type s2. Regarding the geographical distribution of the vacA alleles, the frequency with which type s1 was detected in this study was similar to that found in France, Canada, Italy and the United States. Higher rates were reported in studies conducted in South America (71.4\%) (29) and the central portion of Brazil (72.7\%) (2).

Some authors propose that the prevalence of the s1 allele in peptic ulcer disease would be greater compared to that of the s2 allele, since the former would induce secretion of greater amounts of active cytotoxins and should, for that reason, be considered more virulent (4). In this study, only three patients presented with peptic ulcer, two of them carried the s1 allele.

Analysis of the alleles of the $m$ region showed that $54 \%$ of the samples were identified as $\mathrm{m} 1$ and $46 \%$ as $\mathrm{m} 2$. The alleles of the middle region $(\mathrm{m} 1$ and $\mathrm{m} 2$ ) are associated with the levels of cytotoxin produced, with the allele $\mathrm{ml}$ being associated with the production of higher amounts of the toxin (3). In general, the $\mathrm{m}$ alleles are distributed more evenly than the s alleles, with half of the samples carrying $\mathrm{m} 1$ and the other half $\mathrm{m} 2$ (28). Although this was confirmed by our study, this finding contrasts with the results reported by Brazilian researchers (24), who observed the presence of the $\mathrm{m} 1$ and $\mathrm{m} 2$ alleles in 35 and $65 \%$ of the samples analyzed, respectively.

There is controversy in literature about the association between the s1m1 genotype and the development of peptic ulcer, although some authors suggest a greater frequency of the allele among individuals with the disease (10). Even though only three patients presented with this symptomatology, two of them carried the $\mathrm{s} 1 \mathrm{~m} 1$ allele $(p=1.0)$.

It is believed that patients infected with more virulent $H$. 
pylori strains may develop "protection" against reflux esophagitis, i.e. they would be inversely associated with the onset of the disease (20). Several hypotheses have been formulated in an attempt to explain this phenomenon. One of these hypotheses postulates that this protective effect would be due to the reduction in acid secretion induced by infections caused by more virulent strains. Other hypotheses suggests that, in addition to the virulence factors of the bacterium, host genetic factors should contribute to this process (15). In the present study, the less virulent strains $(\mathrm{s} 2 \mathrm{~m} 2)$ of the vacA were present in greater percentage (45\%) in the patients with reflux esophagitis, however without statistical significance $(p=0.718)$.

Like the vacA gene, the prevalence of $\operatorname{cag} A$-positive samples varies between geographical regions. The frequency of the patients included in this study that carried the $\operatorname{cag} A$ gene was $92 \%$. In large parts of Western Europe and the United States, the prevalence of $\operatorname{cag} A$-positive samples varies between 59 and 75\%; Italy and Portugal exhibit rates greater than $80 \%$, while in Mexico, practically the whole population carries the gene (15).

Several studies have demonstrated that infections caused by $\operatorname{cag} A$-positive $H$. pylori strains are associated with greater intensity of intestinal inflammation, activity, atrophy and metaplasia (1). According to Parsonnet and collaborators, patients infected by these strains would have a three times greater risk of developing gastric cancer (15). On the other hand, Gatti and collaborators (14) did not find any association between $\operatorname{cag} A$-positive samples and chronic gastritis, in spite of the fact that most of the samples analyzed in their study were $\operatorname{cag} A$ positive, suggesting that other bacterial factors may be involved in the pathogenesis of this disease, in addition to the host characteristics.

An association between the prevalence of the $\operatorname{cag} A$ gene and severe diseases such as peptic ulcer suggested by some authors (6), was not observed $(p=1.0)$. However, the high prevalence of this gene in other diseases, such as gastritis and reflux esophagitis, suggests that the gene may not be considered a specific marker of severity in our environment.

Thus, the data generated in this study demonstrate that the genetic profiles determined for the $H$. pylori isolates in this specific region of the country are different from those reported by other Brazilian authors, thereby emphasizing the importance of regional studies. Furthermore, the correlation between the clinical findings and the bacterial genotypes investigated may contribute to a better understanding of the infections associated with this microrganism.

\section{REFERENCES}

1. Álvares, M.M.D.; Marino, M.; Oliveira, C.A.; Mendes, C.C.; Costa, A.C.F.; Guerra, J.; Queiroz, D.M.M.; Nogueira, A.M.M.F. (2006). Características da gastrite crônica associada a Helicobacter pylori: aspectos topográficos, doenças associadas e correlação com o status cagA. J. Bras. Patol. Med. Lab., 42:51-59.

2. Ashour, A.A.R.; Magalhães, P.P.; Mendes, E.N.; Collares, G.B.; De Gusmão, V.R.; Queiroz, D.M.M.; Nogueira, A.M.M.F.; Rocha, G.A.; De Oliveira, C. (2002). Distribution of vacA genotypes in Helicobacter pylori strains isolated from Brazilian adult patients with gastritis, duodenal ulcer or gastric carcinoma. FEMS Immunol. Med. Microbiol., 33:173-178.

3. Atherton, J.C; Cao, P.; Peek Jr, R.M.; Tummuru, M.K.; Blaser, M.J.; Cover, T.L. (1995). Mosaicism in vacuolating cytotoxin alleles of Helicobacter pylori. Association of specific vacA types with cytotoxin production and peptic ulceration. J. Biol. Chem., 270:17771-17777.

4. Atherton, J.C.; Peek Jr, R.M.; Tham, K.T.; Cover, T.L. (1997). Clinical and pathological importance of heterogeneity in $v a c A$, the vacuolating cytotoxin gene of Helicobacter pylori. Gastroenterology, 112:92-99.

5. Bittencourt, P.F.S.; Rocha, G.A.R.; Penna, F.J.; Queiroz, D.M.M. (2006). Gastroduodenal peptic ulcer and Helicobacter pylori infection in children and adolescents. J. Pediatr., 82:325-334.

6. Brito, C.A.A.; Silva, L.M.B.; Juca, N.; Leal, N.C.; Souza, W.; Queiroz, D.; Cordeiro, F.; Silva, N.L. (2003). Prevalence of $\operatorname{cag} A$ and vacA genes in isolates from patients with Helicobacter pylori-associated gastroduodenal diseases in Recife, Pernambuco, Brazil. Mem. Inst. Oswaldo Cruz, 98:817-821.

7. Brown, L.M. (2000). Helicobacter pylori: epidemiology and routes of transmission. Epidemiol. Rev., 22:283-297.

8. César, A.C.G.; Cury, P.M.; Payão, S.L.M.; Liberatore, P.R.; Silva, A.E. (2005). Comparison of histological and molecular diagnosis of Helicobacter pylori in benign lesions and gastric adenocarcinoma. Braz. 
J. Microbiol., 36: 12-16.

9. Datta, S.; Chattopadhyay, S.; Nair, G.B.; Mukhopadhyay, A.K.; Hembram, J.; Berg, D.E.; Saha, D.R.; Khan, A.; Santra, A.; Bhattacharya, S.K.; Chowdhury, A. (2003). Virulence genes and neutral DNA markers of Helicobacter pylori isolates from different ethnic communities of West Bengal, India. J. Clin. Microbiol., 41:3737-3743.

10. Evans, D.G.; Queiroz, D.M.M.; Mendes, E.N.; Evans Jr, D.J. (1998). Helicobacter pylori cagA status and $\mathrm{s}$ and $\mathrm{m}$ alleles of vacA in isolates from individuals with a variety of $H$. pylori-associated gastric disease. $J$. Clin. Microbiol., 36:3435-3437.

11. Kusters, J.G.; Van Vliet, A.H.; Kuipers, E.J. (2006). Pathogenesis of Helicobacter pylori infection. Clin. Microbiol., 19: 449-490.

12. Francisco Jr, A.; Payão, S.L.M.; Queiroz, V.F.; Ellinger, F.; Silva, L.C.; Therezo, A.L.S.; Gatti, L.; Barbieri, D.; Peres, C.A. (2004). Detecção gástrica de Helicobacter pylori em pacientes pediátricos sintomáticos através da reação em cadeia de polimerase (PCR), teste de urease e exame histológico. Pediatria, 26:34-42.

13. Frenck Jr, R.W.; Clemens J. (2003). Helicobacter in the developing world. Microbes. Infect., 5: 705-13.

14. Gatti, L.L.; Labio, R.; Silva, L.C.; Smithand, M.A.; Payão, S.L. (2006). cagA Positive Helicobacter pylori in Brazilian Children Related to Chronic Gastritis. Braz. J. Infect. Dis., 10: 254-258.

15. Godoy, A.P.O.; Miranda, M.C.B; Paulino, L.C.; Mendonça, S.; Ribeiro, M.L.; Pedrazzoli Jr, J. (2007). Análise das impressões digitais de DNA e de fatores de virulência de linhagens de Helicobacter pylori. Arq. Gastroenterol., 44:107-112.

16. Ladeira, M.S.P.; Salvadori, D.M.F.; Rodrigues, M.A.M. (2003). Biopatologia do Helicobacter pylori. Jornal Brasileiro de Patologia e Medicina Laboratorial 39:335-342.

17. Martins, L.C.; Corvelo, T.C.O.; Oti, H.T.; Barile, K.A.S. (2002). Soroprevalência de anticorpos contra o antígeno cagA do Helicobacter pylori em pacientes com úlcera gástrica na região Norte do Brasil. Revista da Sociedade Brasileira de Medicina Tropical 35:307-310.

18. Murray, P.R.; Baron, E.J.; Jorgensen, J.H.; Landry, M.L.; Pfaller, M.A. (2007). Manual of Clinical Microbiology. 9th ed. Washington, D.C: ASM Press.
19. Pacheco, J.B.P.; Anunciação, C.E. (2008). Diagnóstico molecular por PCR dos genes de virulência cagA e vacA de Helicobacter pylori diretamente de biópsia gástrica humana e correlação com gastrite e úlcera. Ensaios e Ciência: C. Biológicas, Agrárias e da Saúde, 12:49-62.

20. Peek Jr, R.M.; Miller, G.G.; Tham, K.T.; Perez-Perez, G.I.; Zhao, X.; Atherton, J.C.; Blaser, M.J. (1995). Heightened inflammatory response and cytokine expression in vivo to cagA+ Helicobacter pylori strains. Lab. Invest., 73:760-770,.

21. Pilonetto M. Soroepidemiologia da infecção pelo Helicobacter pylori em Curitiba. Curitiba, Brasil, 2001 (M.Sc. Dissertation., UFPR).

22. Queiroz, D.M.; Mendes, E.M.; Rocha, G.A. (1987). Indicator medium for isolation of Campylobacter pylori. J. Clin. Microbiol., 25:2378-2379.

23. Ribeiro, M.L.; Ecclissato, C.C.E.; Mattos, R.G.; Mendonça, S.; Pedrazzoli Jr, J. (2007). Quantitative real-time PCR for the clinical detection of Helicobacter pylori. Genetics and Molecular Biology, 30:431-434.

24. Ribeiro, M.L; Godoy, A.P.; Benvengo, Y.H.; Mendonca, S.; Pedrazzoli Jr, J. (2003). Clinical relevance of the $\operatorname{cag} A, v a c A$ and iceA genotypes of Helicobacter pylori in Brazilian clinical isolates. FEMS Immunol. Med. Microbiol., 36: 181-185.

25. Rodrigues, M.N.; Queiroz, D.M.M.; Rodrigues, R.T.; Rocha, A.M.C.; Luz, C.R.L.; Braga, L.L.B.C. (2005). Prevalence of Helicobacter pylori infection in Fortaleza, Northeastern Brazil. Revista de Saúde Pública, 39:847-849.

26. Tytgat, G. (2000). Helicobacter pylori: past, present and future. $J$. Gastroenterol. Hepatol., 15:30-33.

27. Van Doorn, L.J.; Figueiredo, C.; Sanna, R.; Plaisier, A.; Schneeberger, P.M.; Boer, W.; Quint, W. (1998). Clinical relevance of the cagA, vacA, and iceA status of Helicobacter pylori. Gastroenterology, 115:58-66.

28. Van Doorn, L.J.; Figueiredo, C.; Sanna, R.; Blaser, M.J.; Quint, W.G.V. (1999). Distinct variants of Helicobacter pylori cagA are associated with vacA subtypes. J. Clin. Microbiol., 37:2306-2311.

29. Yamaoka, Y.; Kodama, T.; Gutierrez, O.; Kim, J.G.; Kashima, K.; Graham, D.Y. (1999). Relationship between Helicobacter pylori iceA, $\operatorname{cag} A$, and vacA status and clinical outcome: studies in four different countries. J. Clin. Microbiol., 37:2274-2279. 